\title{
UPAYA MENINGKATKAN HASIL BELAJAR PESERTA DIDIK KELAS VII-3 SMP NEGERI 5 SABANG MATERI PECAHAN MELALUI PENERAPAN MODEL PEMBELAJARAN KOOPERATIF TGT
}

\author{
Ady Safwan \\ SMP Negeri 5 Sabang, Jl. Tinjau Alam - Balohan Gampong Aneuk Alot, Kota Sabang; \\ adysafwan11@gmail.com.
}

\begin{abstract}
Abstrak. Penelitian ini bertujuan untuk meningkatkan hasil belajar peserta didik kelas VII.3 SMP Negeri 5 Sabang pada pembelajaran materi pacahan dengan penerapan model pembelajaran kooperatif tipe TGT (Team Games Turnament). Penelitian ini merupakan penelitian tindakan kelas yang terdiri dari dua siklus. Pelaksanaan tindakan dan pengumpulan data dilakukan pada bulan Agustus sampai dengan Oktober tahun 2018 dengan peserta didik kelas VII.3 sebagai subjek yang diteliti. Teknik pengumpulan data yang digunakan adalah tes dan observasi. Tes berupa kuis dilaksanakan untuk mengetahui hasil belajar peserta didik secara individu sedangkan observasi dilakukan untuk mengetahui aktivitas guru dalam melaksanakan model pembelajaran kooperatif tipe TGT. Analisis data menggunakan analisis desktiptif. Analisis nilai tes hasil belajar dilakukan dengan analisis pencapaian ketuntasan dengan KKM 70. Rata-rata skor hasil belajar peserta didik siklus I sebesar 25,89 dengan nilai tertinggi 57 dan rata-rata skor hasil belajar siklus II menurun menjadi 7,46 dengan nilai tertinggi 33. Hasil dari penelitian ini menunjukkan bahwa belum terjadi peningkatan hasil belajar peserta didik pada materi pecahan dengan pembelajaran menerapkan model pembelajaran kooperatif tipe TGT. Dengan demikian dapat disimpulkan bahwa penerapan model pembelajaran kooperatif tipe TGT dalam pembelajaran materi pecahan di kelas VII-3 SMP Negeri 5 Sabang belum dapat membantu guru untuk meningkatkan hasil belajar peserta didik.
\end{abstract}

Kata Kunci. kooperatif TGT, hasil belajar, pecahan

\section{THE EFFORT IN IMPROVING LEARNING ACHIEVEMENT OF GRADE VII-3 STUDENTS OF SMP NEGERI 5 SABANG ON FRACTION TOPIC BY APPLYING TGT COOPERATIVE LEARNING MODEL}

\footnotetext{
Abstract. This study aims to improve the learning achievement of grade VII.3 students of SMP Negeri 5 Sabang on fraction topic by applying TGT (Team Games Tournament) cooperative learning model. This is a type of classroom action research consisting of two cycles. The data collection was carried out on August to October 2018, while subject of the study is grade VII.3 students. Data collection technique applied in this study is tests and observations. Quiz tests are carried out to determine the students' learning result individually while observations are conducted to find out the teacher's activities during implementing TGT cooperative learning model. Descriptive analysis
} 
was chosen as the technique of data analysis. Score analysis was carried out by analysing the standard achievement of minimum satndard score 70. The average score of students in the first cycle was 25.89, the highest score was 57. Meanwhile, the average score of the second cycle decreased to 7.46 with the highest score 33. The research result indicates that there has not been an increase in students' learning result in fraction topic by applying TGT cooperative learning model. In conclusion, it can be stated that that the application of the TGT cooperative learning model in learning fractions in class of VII-3 SMP Negeri 5 Sabang cannot help teachers to improve students' learning result.

Keywords: cooperatif TGT, learning achievement, fraction

\section{Pendahuluan}

Hasil ujian nasional mata pelajaran matematika di SMP Negeri 5 Sabang dalam tiga tahun terakhir hanya memperoleh rata-rata kurang dari 50,0. Sementara tahun 2018 rata-rata nilai ujian nasional mata pelajaran matematika adalah 32,5. Salah satu kendala yang dihadapi peserta didik adalah saat menyelesaikan soal-soal yang melibatkan bilangan pecahan. Hal ini juga diperkuat dengan melihat dokumentasi nilai ulangan harian materi pecahan tahun-tahun sebelumnya, dimana hanya sebagian kecil peserta didik yang mendapat nilai ulangan harian mencapai batas KKM sedangkan sebagian besar lainnya harus diberikan remedial. Kenyataan ini menjadi tantangan berat khususnya bagi guru-guru yang mengampu mata pelajaran matematika untuk lebih kreatif dalam merencanakan pembelajaran matematika di masa yang akan datang.

Salah satu penyebab peserta didik kurang menguasai materi pecahan adalah kurang tepatnya model pembelajaran/pendekatan dan strategi yang digunakan guru dalam melaksanakan pembelajaran yang mengakibatkan peserta didik dominan belajar dalam suasana pasif. Guru belum mampu menghadirkan model pembelajaran yang mampu membangkitkan interaksi yang efektif antara peserta didik dengan guru ataupun peserta didik sesama peserta didik.

Strategi yang dapat dikembangkan dengan tujuan agar pembelajaran dapat berjalan aktif dan bermakna bagi peserta didik adalah melalui penerapan model pembelajaran kooperatif. Team Gemes Tournament (TGT) adalah salah satu tipe atau model pembelajaran kooperatif yang mudah diterapkan, melibatkan aktivitas seluruh peserta didik tanpa ada perbedaan status, melibatkan peran peserta didik sebagai tutor sebaya, dan mengandung unsur permainan dan reinforcement. Aktivitas belajar dengan TGT memungkinkan peserta didik dapat belajar dengan rileks disamping menumbuhkan tanggung jawab, kerjasama, persaingan sehat dan keterlibatan belajar.

Berdasarkan uraian di atas dapat dirumuskan masalah sebagai berikut: 1) Apakah model pembelajaran kooperatif TGT dapat membantu guru meningkatkan hasil belajar peserta didik dalam pembelajaran materi pecahan? 2) Bagaimanakah peningkatan hasil belajar peserta didik jika pembelajaran dilakukan dengan menggunakan model pembelajaran kooperatif TGT? 


\section{Kajian Pustaka}

\subsection{Belajar Matematika}

Belajar adalah proses perubahan yang terjadi pada seseorang yang mencakup pengetahuan, ketrampilan dan tingkah laku (sikap) sebagai hasil dari pengalaman yang diperoleh melalui membaca, mengamati, mendengar, meniru, latihan dan sebagainya. Hudoyo (1990) menyatakan bahwa "seseorang dikatakan belajar matematika apabila pada dirinya terjadi suatu kegiatan yang dapat mengakibatkan perubahan tingkah laku yang berkaitan dengan matematika, seperti perubahan dari tidak tahu suatu konsep matematika menjadi tahu konsep tersebut dan mampu menggunakannya untuk mempelajari materi lebih lanjut maupun dalam kehidupan sehari-hari."

Dari uraian tersebut, maka dapat ditarik suatu pemahaman bahwa, dalam penelitian ini yang dimaksud dengan belajar matematika adalah suatu kegiatan yang dilakukan peserta didik untuk mendapatkan perubahan pengetahuan, ketrampilan dan sikap sebagai hasil dari pengalaman yang diperoleh melalui membaca, mengamati, mendengar, meniru dan serangkaian aktivitas latihan yang melibatkan proses kognitif berkaitan dengan matematika.

\subsection{Hasil Belajar}

Hasil belajar adalah kemampuan yang diperoleh peserta didik dalam bentuk perubahan perilaku, sikap atau ketrampilan setelah menerima pengalaman belajar pada suatu kompetensi tertentu. Hasil belajar yang dimaksud dalam penelitian ini adalah kemampuan yang diperoleh peserta didik berupa hasil ulangan harian setelah mengikuti pembelajaran matematika pada materi bilangan pecahan.

\subsection{Pembelajaran Kooperatif}

Pembelajaran kooperatif merupakan model pembelajaran yang mengutamakan adanya kerja sama, yakni kerjasama antar peserta didik dalam kelompok untuk mencapai tujuan pembelajaran. Dalam pembelajaran kooperatif, peserta didik bekerja bersama-sama untuk mempelajari dan menyelesaikan suatu masalah. Keberhasilan kelompok akan tercapai hanya jika setiap anggota kelompok berhasil memahami konsep atau materi yang diajarkan. Dengan demikian, tugas para peserta didik bukanlah melakukan sesuatu tetapi mempelajari sesuatu sebagai sebuah kelompok, dimana kerja kelompok dilakukan sampai semua anggota kelompok menguasai materi yang sedang dipelajari.

Hamdani (2010) menguraikan beberapa unsur dasar dalam pembelajaran kooperatif sebagai berikut:

a. Para peserta didik harus memiliki persepsi bahwa mereka "tenggelam atau berenang bersama."

b. Para peserta didik harus memiliki tanggung jawab terhadap peserta didik lain dalam satu kelompok, selain tanggung jawab terhadap diri sendiri dalam materi yang dihadapi.

c. Para peserta didik harus berpandangan bahwa mereka memiliki tujuan yang sama.

d. Para peserta didik berbagi tugas dan tanggung jawab di antara anggota kelompok. 
e. Para peserta didik diberikan satu evaluasi atau penghargaan yang ikut berpengaruh terhadap evaluasi kelompok.

f. Para peserta didik berbagi kepemimpinan dan mereka memperolah keterampilan bekerja sama selama belajar.

g. Setiap peserta didik akan diminta mempertanggungjawabkan secara individual materi yang ditangani dalam kelompok kooperatif.

\subsection{Pembelajaran Kooperatif TGT}

Pembelajaran kooperatif model TGT melibatkan aktivitas seluruh peserta didik tanpa ada perbedaan status, melibatkan peran peserta didik sebagai tutor sebaya dan mengandung unsur permainan dan reinforcement. Dalam TGT para peserta didik berlomba sebagai wakil tim mereka dengan anggota tim lain yang memiliki kemampuan akademik sebelumnya setara seperti mereka sehingga memungkinkan setiap anggota tim dari semua tingkat kemampuan akademik berkontribusi secara maksimal terhadap skor tim mereka.

Slavin (2015) mendiskripsikan bahwa TGT terdiri atas lima komponen utama yaitu presentsi kelas, tim atau kelompok, game, turnamen dan rekognisi tim.

\section{a. Presentasi Kelas}

Materi pembelajaran dalam TGT pertama-tama diperkenalkan dalam presentasi di dalam kelas yang dilakukan melalui pembelajaran langsung atau dikusi yang dipimpin oleh guru dan juga dimungkinkan presentasi melalui audiovisual. Presentasi kelas harus benar-benar berfokus pada pencapaian tim sehingga peserta didik menyadari bahwa mereka harus benarbenar memberikan perhatian penuh selama presentasi kelas belangsung karena sangat membantu mereka saat turnamen agar dapat memberikan kontribusi maksimal terhadap skor tim mereka.

\section{b. Tim}

Tim terdiri dari empat atau lima peserta didik yang mewakili seluruh bagian dari kelas dalam hal kemampuan akademik, jenis kelamin, ras maupun etnis. Fungsi utama tim adalah memastikan semua anggota tim benar-benar belajar dan yang lebih khusus lagi adalah mempersiapkan anggotanya untuk tampil optimal saat pelaksanaan game di meja turnamen. Yang perlu ditekankan dalam tim adalah bagaimana membuat anggota tim melakukan yang terbaik untuk tim dan tim juga harus melakukan yang terbaik untuk membantu anggotanya.

\section{c. Game}

Game terdiri atas pertanyaan-pertanyaan dengan konten yang relevan dirancang untuk menguji pengetahuan peserta didik yang diperolehnya dari presentasi kelas dan pelaksanaan kerja tim yang dimainkan di atas meja dengan tiga orang peserta didik yang masing-masing mewakili tim yang berbeda.

\section{d. Turnamen}

Turnamen adalah sebuah struktur dimana game dilangsungkan. Turnamen dilaksanakan pada akhir pertemuan setelah guru memberikan presentasi di kelas dan tim telah melaksanakan kerja kelompok untuk menyelesaikan lembar kegiatan. Pada turnamen pertama guru menunjuk peserta didik untuk berada pada meja turnamen. Tiga siswa dengan kemampuan 
akademik tinggi dari tim berbeda ditempatkan pada meja pertama, tiga berikutnya pada meja kedua dan seterusnya.

e. Rekognisi Tim

Tim akan mendapat sertifikat atau bentuk penghargaan yang lain apabila skor rata-rata mereka mencapai kriteria tertentu.

\subsection{Hipotesis Tidakan}

Berdasarkan kerangka teori di atas maka hipotesis penelitian ini dirumuskan sebagai berikut:"Jika pembelajaran dilakukan dengan menerapkan model pembelajaran kooperatif TGT, maka hasil belajar peserta didik kelas VII-3 SMP Negeri 5 Sabang pada materi pecahan akan meningkat"

\section{Pelaksanaan}

Penelitian ini berbentuk penilitian tindakan kelas (PTK) dengan subjek penelitian adalah peserta didik kelas VII-3 SMP Negeri 5 Sabang tahun ajaran 2018/2019 dengan jumlah 28 peserta didik.

Model desain dalam penelitian ini mengacu pada model Kemmis dan Mc Taggart seperti dikemukakan oleh Uno (2012) terdiri dari komponen planning, acting and observing, reflecting yang dapat digambarkan seperti gambar berikut.

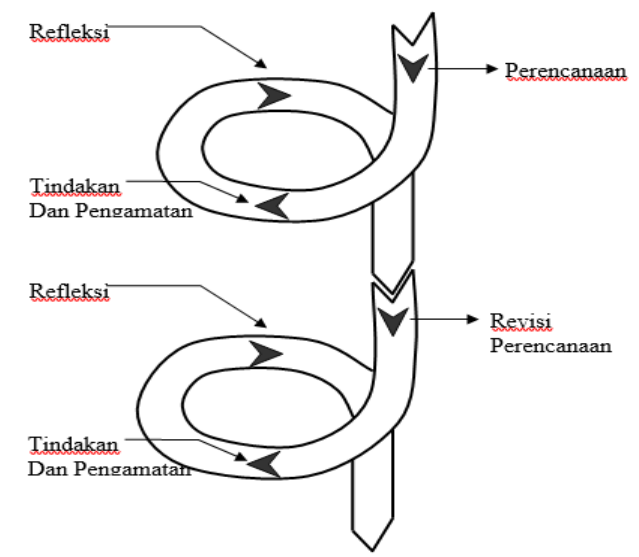

Gambar 1. Desain PTK Model Kemmis \& Mc Taggart

Sumber data dalam penelitian ini adalah hasil tes individu/kuis dan hasil pengamatan kemampuan guru dalam mengelola pembelajaran yang dilaksanakan pada setiap akhir siklus.

Instrumen yang digunakan dalam penelitian ini adalah soal tes individu/kuis dan lembar pengamatan kemampuan guru dalam mengelola pembelajaran. Pengumpulan data dilakukan dengan cara sebagai berikut:

Data tentang hasil tes individu/kuis dikumpulkan dengan menggunakan instrument tes hasil belajar individu/kuis yang dilaksanakan setelah akhir kegiatan pembelajaran dan pelaksanaan 
turnamen (peserta didik telah mempelajari seluruh materi pembelajaran/selesai 1siklus tindakan). Sedangkan data tentang kemampuan guru dalam mengelola pembelajaran menggunakan model kooperatif TGT dikumpulkan dengan menggunkan lembar observasi yang dilakukan oleh seorang guru pengamat selama berlangsungnya proses pembelajaran.

Analisa data dilakukan menggunakan analisis deskriptif yang dapat diuraikan secara singkat sebagai berikut. Nilai hasil tes individu/kuis dilakukan dengan analisis ketercapaian ketuntasan dengan batas ketuntasan adalah KKM Matematika kelas VII yaitu 70. Sedangkan analisa data tentang kemampuan guru mengelola pembelajaran dilakukan dengan persentase. Persentase pengamatan kemampuan guru diperoleh dari jumlah total perolehan skor hasil pengamatan dibagi dengan skor maksimum seluruh aspek yang diamati dikalikan $100 \%$. Kemampuan guru mengelola pembelajaran berada dalam kategori baik jika aspek yang diamati tercapai lebih dari $76 \%$.

Kondisi akhir yang diharapkan setelah pelaksanaan penelitian ini adalah adanya peningkatan hasil belajar peserta didik. Pembelajaran dengan menerapkan model pembelajaran kooperatif TGT dikatakan mampu meningkatkan hasil belajar peserta didik jika minimal $75 \%$ dari peserta didik yang ada pada kelas VII-3 SMP Negeri 5 Sabang memperoleh nilai lebih dari atau sama dengan nilai KKM yaitu 70 .

Pelaksanaan tindakan kelas ini telah penulis laksanakan dari tanggal 20 Agustus 2018 sampai dengan 26 Oktober 2018.

\subsection{Deskripsi Siklus I}

\subsubsection{Perencanaan Tindakan}

Dalam rangka persiapan, peneliti menyiapkan RPP, lembar diskusi tim, soal game untuk turnamen, soal kuis individu, dan lembar observasi kemampuan guru mengelola pembelajaran. Di samping itu peneliti menunjuk seorang guru yang bertindak sebagai observer selanjutnya berdiskusi untuk pembentukan kelompok/tim dan penempatan peserta didik dalam meja turnamen.

\subsubsection{Pelaksanaan Tindakan}

Tindakan pertama dilaksanakan berupa pembelajaran materi mengurutkan bilangan pecahan yang disampaikan secara langsung oleh guru melalui presentasi kelas. Aktivitas selanjutnya dilaksanakan sesuai dengan RPP yang telah direncanakan yaitu peserta didik bekerja dalam kelompok menyelesaikan soal-soal yang sudah disiapkan oleh guru dalam lembar diskusi kelompok/tim. Pada tahap ini diharapkan semua anggota tim dapat mengambil peran dalam menyelesaikan soal-soal dalam lembar diskusi tim. Peserta didik dengan kemampuan yang tinggi membantu anggota tim yang memiliki kemampuan di bawahnya. Hal ini penting karena penguasaan materi oleh seluruh anggota tim dengan baik akan berdampak pada perolehan poin masing-masing tim saat turnamen mengingat skor tim saat turnamen adalah rata-rata skor dari skor yang diperoleh seluruh anggota tim pada meja turnamen masingmasing. Pertemuan selanjutnya adalah pelaksanaan turnamen dan tes hasil belajar individu. 


\subsubsection{Hasil Pengamatan}

\subsubsection{Data Nilai Tes Hasil Belajar/Kuis}

Dari data tentang hasil belajar peserta didik diperoleh bahwa skor rata-rata hasil tes individu peserta didik yaitu 25,89 dengan skor tertinggi adalah 57 dan tidak ada peserta didik yang memperoleh skor lebih dari atau sama dengan nilai ketuntasan minimal yaitu 70. Dengan kata lain hasil tes individu kuis 1 nilai ketuntasan adalah $0 \%$.

\subsubsection{Data Hasil Observasi Aktivitas Guru}

Dari data hasil pengamatan aktivitas guru dalam melaksanakan pembelajaran diperoleh jumlah skor 90 dari skor total semua indikator 108. Dengan kata lain aktivitas guru dalam melaksanakan pembelajaran dengan menerapkan model pembelajaran kooperatif TGT terlaksana $83 \%$ yang masuk dalam kategori baik.

\subsubsection{Refleksi}

Memperhatikan hasil dari ketiga hal di atas maka dapat disimpulkan bahwa indikator kinerja belum tercapai. Dengan demikian siklus ke 2 dilaksanakan dengan melakukan beberapa perbaikan pada pelaksanaan tindakan.

\subsection{Deskripsi Siklus 2}

\subsubsection{Perencanaan Tindakan}

Berdasarkan hasil yang diperoleh pada siklus 1, maka akan dilaksanakan siklus 2. Pada aktivitas kerja tim dalam siklus 2 ini peserta didik dibekali bahan cetak berkaitan dengan materi penjumlahan dan pengurangan pecahan. Disamping itu jumlah soal yang disajikan dalam lembar diskusi tim juga dikurangi.

\subsubsection{Pelaksanaan Tindakan}

Pelaksanaan tindakan siklus 2 masih seperti pelaksanaan tindakan pada siklus 1 yang dilaksanakan dalam dua pertemuan dengan materi operasi penjumlahan dan pengurangan bilangan pecahan. Yang berbeda adalah dalam pelaksanaan siklus II pada saat peserta didik bekerja dalam tim, selain dibekali dengan buku siswa sebagai sumber belajar juga diberikan bahan cetak lain yang berkaitan dengan materi yang dipelajari yang sudah disiapkan oleh guru. 


\subsubsection{Hasil Pengamatan}

\subsubsection{Data Nilai Tes Hasil Belajar/Kuis}

Dari data tentang hasil belajar peserta didik diperoleh bahwa skor rata-rata hasil tes individu peserta didik yaitu 7,46 pada skala nilai 0 - 100 dengan skor tertinggi adalah 33 dan tidak ada peserta didik yang memperoleh skor lebih dari atau sama dengan nilai ketuntasan minimal yaitu 70. Dengan kata lain hasil tes individu kuis 1 nilai ketuntasan adalah $0 \%$. Salah satu faktor penyebab skor rata-rata menurun adalah terdapat 5 orang peserta didik yang tidak hadir pada pertemuan pelaksanaan turnamen dan tes hasil belajar individu/kuis. Dari 5 peserta didik yang tidak hadir terdapat peserta didik yang memiliki kemampuan tinggi.

\subsubsection{Data Hasil Observasi Aktivitas Guru}

Dari data hasil pengamatan aktivitas guru dalam melaksanakan pembelajaran diperoleh jumlah skor 92 dari skor total semua indikator 108. Dengan kata lain aktivitas guru dalam melaksanakan pembelajaran dengan menerapkan model pembelajaran kooperatif TGT terlaksana $85 \%$ yang masuk dalam kategori baik.

\subsubsection{Refleksi}

Memperhatikan hasil dari ketiga hal di atas maka dapat disimpulkan bahwa indikator kinerja belum tercapai. Karena sudah 2 siklus dilaksanakan belum ada tanda-tanda peningkatan pada hasil belajar peserta didik maka penulis memutuskan untuk tidak melanjutkan ke siklus berikutnya. Di samping itu juga penulis menemukan bahwa sebagian besar peserta didik masih kesulitan dalam melakukan perkalian bilangan asli 1 sampai dengan 10 dan ini berpengaruh kepada keberhasilan peserta didik dalam mempelajari materi operasi penjumlahan dan pengurangan serta operasi perkalian dan pembagian pada bilangan pecahan karena materi perkalian bilangan bulat adalah materi prasyaratnya.

\section{Pembahasan}

Pada siklus 1, indikator kinerja belum terpenuhi, ini terlihat dari hasil belajar individu belum ada peserta didik yang memperoleh skor mencapai KKM atau lebih.oleh karena itu, maka berdasarkan hasil diskusi dengan kolaborator untuk melanjutkan tindakan ke siklus 2 dengan beberapa perbaikan antara lain: 1) Memberikan pemahaman kepada setiap kelompok bahwa dalam pembelajaran kooperatif menganut prinsip berenang atau tenggelam bersama, artinya jika ada anggota kelompok yang belum memahami suatu materi maka seluruh anggota tim bertanggung jawab karena pada saat turnamen semua anggota memiliki kontribusi untuk menyumbang skor sebagai nilai tim. 2) Guru diharapkan lebih aktif untuk mendorong peserta didik agar mau bertanya kepada guru atau kawan satu tim terlebih pada saat peserta didik mengerjakan lembar diskusi tim. 3) Mengurangi jumlah soal pada lembar diskusi tim dan lembar game untuk turnamen dengan harapan waktu yang tersedia cukup untuk mengerjakannya. 4) Memberikan lembar materi yang disusun dalam bentuk contoh-contoh soal dan penyelesaian terkait operasi penjumlahan dan pengurangan bilangan pecahan 
sebagai referensi tambahan di samping buku siswa yang dapat digunakan peserta didik saat mengerjakan lembar diskusi tim.

Pada siklus 2, indikator kinerja belum tercapai, ini terlihat dari hasil belajar individu belum ada peserta didik yang memperoleh skor mencapai KKM atau lebih. Disamping itu peneliti dan pengamat juga menemukan bahwa peserta didik menemukan kendala pada saat menyamakan penyebut dua pecahan yang memiliki penyebut berbeda sebelum menjumlahkan atau mengurangkan pecahan. Hal ini terjadi karena sebagian peserta didik tidak menguasai dengan baik perkalian dasar bilangan asli 1 sampai 10. Karena itu, peneliti berdiskusi dengan guru kolaborator untuk menghentikan tindakan sampai di siklus 2, disamping itu penelitian ini juga dibatasi pada lingkup materi bilangan pecahan sehingga tidak mungkin dilanjutkan lagi ke siklus berikutnya.

\section{Kesimpulan dan Saran}

\subsection{Kesimpulan}

Pembelajaran matematika.materi pecahan dengan menerapkan model pembelajaran kooperatif TGT belum mampu membantu guru untuk meningkatkan hasil belajar peserta didik kelas VII-3 SMP Negeri 5 Sabang tahun ajaran 2018/2019. Hal ini terlihat dari perolehan hasil tes individu pada dua siklus yang dilaksanakan belum ada peserta didik yang mendapat nilai mencapai KKM yaitu 70 atau lebih. Dengan kata lain persentase ketuntasan belajar peserta didik adalah $0 \%$.

\subsection{Saran}

Kepada guru-guru matematika diharapkan dapat mencoba model-model pembelajaran yang lain dalam rangka menciptakan pembelajaran matematika yang aktif, inovatif, kreatif dan menyenangkan untuk meningkatkan hasil belajar peserta didik dengan mempertimbangkan kemampuan prasyarat yang dimiliki peserta didik untuk setiap materi pembelajaran.

\section{Daftar Pustaka}

Anita Lie. 2014. Cooperative Learning. Jakarta: Gramedia Widiarsana Indonesia. Arikunto, Suharsimi. 2014. Penelitian Tindakan Kelas. Jakarta: Bumi Aksara. Hamdani. 2010. Strategi Belajar Mengajar. Bandung: Pustaka Setia. Hudoyo, Herman. 1990. Mengajar Belajar Matematika. Malang: IKIP. Slavin. Robert E, 2015. Cooperative Learning Teori, Riset dan Praktik. Bandung: Nusa Media. Tanireja, Tukiran. 2015. Penelitian Tindakan Kelas. Bandung: Alfabeta.

Uno, Hamzah, 2012. Menjadi Peneliti PTK yang Profesional. Jakarta; Bumi Aksara.

\section{How to Cite:}

Safwan, A. (2019). Upaya Meningkatkan Hasil Belajar Peserta Didik Kelas VII-3 SMP Negeri 5 Sabang Materi Pecahan Melalui Penerapan Model Pembelajaran Kooperatif TGT. IDEAL MATHEDU: Indonesian Digital Journal of Mathematics and Education, 6(1), 583-591. 